\title{
Proximal and sensory analysis of red tilapia (Oreochromis sp.) fed with fish tanks sediments from a Biofloc culture
}

\author{
Daniel Leonardo Cala DELGADO ${ }^{1,2}$ (D), Caled Alvarez RUBIO², Victor Alexander Cueva QUIROZ
}

\begin{abstract}
Feeding accounts for 50\%-60\% of production costs in fish farming, and alternative raw materials are used to lower production costs. These raw materials can alter nutritional values and sensory aspects of the final product. The present study describes the results for the proximal composition, sensory, and microbiological analyses of red tilapia (Oreochromis sp.) fed with a biofloc meal (fish sediment residue). The results showed that the red tilapia biofloc meal contained protein levels over 30\%, with 3\% nitrogen and $6 \%$ calcium. Fish fed biofloc meal showed productive performances within the ranges established for the species. Sensory analysis revealed that the cooked product's appearance was very characteristic, presenting a slight metallic flavor and moderate juiciness. The bromatological composition analysis indicated that each $100 \mathrm{~g}$ of tilapia contained $16 \mathrm{~g}$ of protein. Finally, the microbiological study guarantees compliance with the local tandards and confirms that the product does not contain significant levels of microorganisms that could cause foodborne diseases when consumed by humans. In conclusion, the use of biofloc meal at a small red tilapia farm proved to be a sustainable alternative for feeding Oreochromis sp.
\end{abstract}

Keywords: alternative protein; floc meal; protein feed; biofloc technology; sustainable.

Practical Application: Microbial flocs produced in a red tilapia biofloc system could offer the small-scale tilapia industry a novel alternative feed, rich in protein and minerals, without compromising the zootechnical performance or the microbiological and sensory quality of the fish. The study communicates the use of an alternative tilapia diet including floc meals at a commercial scale, showing its high practical application.

\section{Introduction}

Feeding accounts for $50 \%-60 \%$ of fish farming production costs, which is approximately COP $\$ 2,813$ (USD \$1) for each kilogram of fish (Brú-Cordero et al. 2017). In order to develop sustainable aquaculture systems, alternative sources of high quality protein, the main limiting factor, will have to be identified to replace high-cost ingredients (Mbahinzireki et al., 2001; Bauer et al., 2012). Studies indicate that just about $20-35 \%$ of the nitrogen from fish diets is actually retained, with the remainder being lost as ammonia and organic nitrogen in feces and feed residue (Najdegerami et al, 2016). Recycling of nutrients occurs within fish tanks, and they can be used as an agricultural fertilizer or for feeding aquatic organisms at reduced scales (Hargreaves, 2013). Therefore, it is important to determine if alternative ingredients such as derived from biologically treating fish waste could be a suitable replacement ingredient for aquaculture diets, offering a sustainable option to fishmeal or even soy meal (Kuhn et al., 2010).

Biofloc technology (BFT) is a limited or zero water exchange productive system, which ensures intensification and sustainable feeding management (Crab et al., 2012). Bioflocs are heterogeneous aggregates of suspended organic particles and associated microorganism, including bacteria, fungi, flagellates, protozoans, ciliates, algae, among others (Luo et al., 2020). Bioflocs are a rich protein source (Xu \& Pan, 2012), and

could be used as alternative ingredients to replace traditional protein sources used in small aquaculture production facilities (Hargreaves, 2013). Proximal analysis of biofloc meals from Nile tilapias, Oreochromis niloticus, showed that protein content can range from $17.92 \%$ to $24.5 \%$, and that this depends on the feed used during the production process (Prabu et al., 2017; Mabroke et al., 2019), similar findings have been obtained for shrimps (Xu \& Pan, 2012).

Bioflocs can supplement a portion of food protein for low protein feeds and also contribute to maintaining physiological functions in Pacific white shrimp, Litopenaeus vannamei (Ju et al., 2008; Bauer et al., 2012; Kuhn et al., 2009, 2010; Xu \& Pan., 2014) and tiger shrimp, Penaeus monodon (Anand et al., 2014). In addition, appropriate dietary biofloc level in the diet of sea cucumbers, Apostichopus japonicas, improved the growth performance by accelerating protein turnover and optimizing energy allocation, proving to be a sustainable protein (Chen et al., 2018). Nevertheless, no previous studies have investigated the use of biofloc meals as alternative feeding for red tilapias cultured in BFT aquaculture systems.

Thus, the objective of this work was to describe the performance an alternative diet including a biofloc meal for feeding of red tilapia farmed in a BFT system: including proximal composition 
of the sediments and tilapia fillets and microbiological and sensory analysis.

\section{Materials and methods}

The study was prepared with data obtained from a commercial BFT fish farm: "El Vergel" Fish Association, localized in the municipality of Arauquita, Colombia. The facility used biofloc meal to feed red tilapias and performed all the analysis described in the present study as part of their own productive cycle and quality controls of their final product.

\subsection{Experimental design}

Juveniles of red tilapia (Oreochromis sp.), average weight $24 \pm 0.1 \mathrm{~g}$, were stocked in 19 polyethylene tanks $\left(153 \mathrm{~m}^{3}\right)$, diameter $14 \mathrm{~m}(\mathrm{n}=5000)$, within a BFT system, and fed with constant artificial diet for 90 days. Details about the productive system are described in section 2.2. The artificial diet was prepared using local ingredients including a biofloc meal obtained from six months fish tanks residues from a prior batch at the commercial facility (Table 1). At the end of the feeding trial, fish were measured, and random samples of fish fillets were analyzed for its bromatological content, sensory analysis and microbiological quality.

\subsection{Biofloc production}

Biofloc production was carried out in a red tilapia commercial production system that implemented biofloc technology and was managed as per the methodology recommended by Avnimelech (2009). The carbon to nitrogen ratio was maintained at 20:1. Molasses with $480 \mathrm{~g}$ of carbon per $\mathrm{kg}$ was used to maintain this ratio to generate a heterotrophic environment indicated for the growth of microorganisms that convert ammonium to nitrite and subsequently to nitrate. When the biofloc became mature, indicated by the optimal amount of decantable solids (between 25 and $50 \mathrm{ml} \mathrm{L}^{-1}$ of water), the carbon to nitrogen ratio was modified to 6:1 and the amount of molasses was calculated depending on the amount of ammonia present in the production system. Agricultural or carbonated lime at a ratio of $10 \%$ of the amount of feed supplied per day was added to maintain an alkalinity above

Table 1. Proximal composition of the diet.

\begin{tabular}{lr}
\hline \multicolumn{1}{c}{ Raw material } & $\%$ \\
\hline Biofloc meal & 20.2 \\
Blood meal & 19.2 \\
Rice meal & 13.0 \\
Cornmeal & 6.5 \\
Viscera meal & 10.4 \\
Tallow & 3.3 \\
Wheat bran & 19.5 \\
Soy cake & 7.2 \\
Mineral premix and Vit & 0.7 \\
TOTAL & 100 \\
\hline
\end{tabular}

$120 \mathrm{ppm}$. High alkalinity values act as a buffer, maintaining $\mathrm{pH}$ at 7 ; this prevented intoxication of the fish by the non-ionized ammonium present in alkaline $\mathrm{pH}$, which increases along with salinity and temperature (Ebeling et al., 2006). All tanks were aerated and mixed continuously using air pumps to meet the oxygen demand.

The decantable solids were removed daily for 6 months using decanters with a capacity of $1 \%$ of the total capacity of the production tank. To achieve this, external tanks were connected through pipes into which water containing high levels of solids slowly entered via an airlift system and flowed toward the surface exit. The solids remained at the bottom because of the effect of gravity and then were collected through a stopcock and subsequently dried at room temperature. The collected floc was processed as indicated by Chen at al. (2018). Biofloc meal was stored at $-20^{\circ} \mathrm{C}$ until experimental diets were made.

Finally, biofloc meal samples were sent to a specialized food laboratory to assess moisture, ash content, crude protein, crude lipid, crude fiber, total carbohydrates, and caloric value. Water content was quantified by means of the AOAC 925.10 gravimetric method, by drying a sample in a hot air oven at $103^{\circ} \mathrm{C}$ for $1 \mathrm{~h}$, and obtaining moisture content by weighting and comparing the sample weight prior and after drying. Lipid content was determined according to the acid hydrolysis method, AOAC 920.85 - Soxhlet extraction. Total protein content was determined using GOMEPL.01 - Kjeldahl method procedure. Ash analysis used carbonization in a muffle furnace at $550{ }^{\circ} \mathrm{C}$ (AOAC 923.03). Fiber was determined by enzymatic-gravimetric method (AOAC 978.10). Energy was calculated as 16.7, 16.7 and $37.7 \mathrm{~kJ} \mathrm{~g}^{-1}$ of protein, carbohydrate and lipids, respectively (Association of Official Analytical Chemists, 2012). Nitrogen was measured using the Kjeldahl titrimetric digestion, while several macro and micronutrient values were assessed by means of spectrophotometry and atomic absorption.

\subsection{Productive performance}

Tilapias were fed the alternative diet five times a day for 90 days (Table 1), at a feeding rate of $3 \%$ of their average weight. At the end of the feeding trial, zootechnical performance parameters were evaluated as indicated in equation 1.

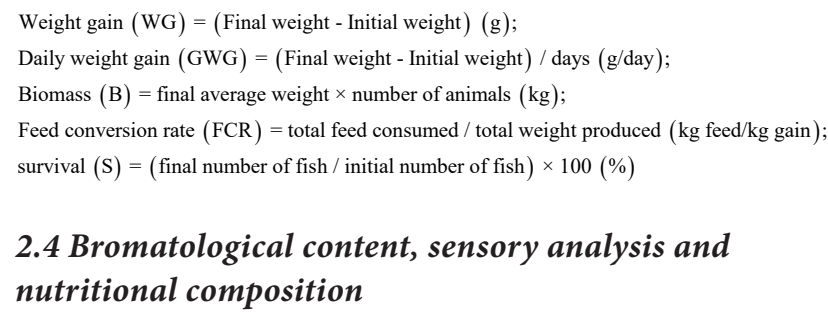

\subsection{Bromatological content, sensory analysis and nutritional composition}

After 90 days of production, five fishes from each tank were sent to an external laboratory to determine their nutritional profile. Samples were dried in an oven at $105^{\circ} \mathrm{C}$ until constant weight, then ground and analyzed for crude protein, crude lipid, and ash contents using the standard methods as used for the biofloc meal (Section 2.2). 
Sensory evaluation was carried out with a trained panel of three persons to evaluate appearance color, odor, flavor, and juiciness. The global score was obtained by consensus in two replications (Amerine et al., 1965). A 0-10 scale was used. All analyses on cooked tilapia fillets were performed at optimal cooking time $\left(70^{\circ} \mathrm{C}\right)$, monitoring through a spit-type thermometer. The samples were divided into $3 \times 3 \mathrm{~cm}$ sizes and packed in aluminum foil.

Additionally, microbiological evaluations were performed, including counts for Escherichia coli, coagulase-positive Staphylococcus aureus, Salmonella spp., and Vibrio cholerae. Bacteriological examinations were conducted immediately after sampling and followed the criteria described by Gatti et al. (2014).

\subsection{Water quality}

The methodology indicated by Delgado et al. (2018) was used for the measurement and recording of water parameters. Temperature, dissolved oxygen concentration, and saturation parameters were measured daily using a YSI EcoSense ${ }^{\varpi}$ DO200A probe. $\mathrm{pH}$, total dissolved solids (TDS), and electrical conductivity (EC) were measured using the Hanna ${ }^{\circledR}$ model 991300 equipment. Chemical parameters, ammonium, nitrite, nitrate, alkalinity, and orthophosphates were evaluated once a week using colorimetric established methodologies. Finally, the volume of total decantable solids (DS) was measured using an Imhoff cone (American Public Health Association, 2005).

\section{Results and discussion}

Numerous studies have reported complete or partial replacement of high cost ingredients such as fishmeal with plant-based ingredients in diets for omnivorous fish and prawns. On the other hand, few studies have addressed biofloc meals as ingredients in aquaculture diets, with most studies focused on prawns. Kuhn et al. $(2009,2010)$ reported high protein content for L. vannamei biofloc meals, showing that the alternative diets improved shrimp growth by an average 11-49\% compare to a control diet. A recent study demonstrated that dietary supplementation of biofloc meal at 4-8\% level had beneficial effects on growth performance and digestive enzyme activities in $P$. monodon (Anand et al., 2014). The present study relates the use of a biofloc meal as an alternative ingredient for red tilapias farmed in a BFT system.

The results of macronutrient and micronutrient analyses (Table 2) showed that the protein levels of the biofloc meal were above $30 \%$ and that the macronutrient with the highest presence in this product was nitrogen (3.03\%). Protein content was higher than reported by Bauer et al. (2012) for microbial floc meal obtained from shrimp BFT tanks (23.39\%) and by Prabu et al. (2017) for GIFT tilapias (17.92\%). In addition, protein levels were similar to those found by Luo et al. (2017) for Nile tilapia bioflocs prepared with different carbon sources. Differences in the protein content of flocs can be related to the nitrogen levels and nitrifying reactions by microorganisms because this nitrogen-reducing action can be evaluated by measuring protein levels in sediments (Luo et al., 2019).
Table 2. Bromatological and nutrient analysis of the biofloc meal (red tilapia sediment residues).

\begin{tabular}{lcr}
\hline \multicolumn{2}{c}{ Bromatological proximal analysis } \\
\hline Humidity & Unit & Value \\
Ash & 10.78 \\
Fat & 30.59 \\
Protein & 0.40 \\
Fiber & 30.26 \\
Total carbohydrates & 4.44 \\
Caloric Value & 27.98 \\
\hline & & 236.51 \\
\hline Nitrogen & \\
Phosphorous & 3.03 \\
Potassium & 0.97 \\
Calcium & 0.30 \\
Magnesium & 6.96 \\
Manganese & & 0.24 \\
Iron & & $<0.01$ \\
Copper & 0.64 \\
Zinc & $<0.01$ \\
Boron & 0.09 \\
Sulfur & 0.92 \\
\hline
\end{tabular}

In fish farming, heterotrophic bacteria directly and rapidly convert accumulated ammonia into bacterial protein, which is reflected in the levels of this product in the sediments (Ebeling et al., 2006). Moreover, microalgae, protozoa, rotifer, oligochaetea detritus and dead organic particles are constantly observed in the sedimentable flocs and can serve as protein sources (Azim \& Little, 2008; Wei et al., 2020).

The high percentage of ash found in the biofloc meal of the present experiment (30.59\%) can be explained by the high salt content in the BFT system and has been observed before in floc meals collected from $L$. vannamei BFT tanks (Ju et al., 2008; Bauer et al., 2012) and Nile tilapia BFT tanks (51.28\%) (Prabu et al., 2017). Additionally, lipid levels found in this study were low, indicating that the tilapia growth was mostly associated to other components from the biofloc meal.

It is estimated that $88 \%$ of the nitrogen accumulated in a fish farming system is related to feed. One way to remove this nutrient is through sediments that represent approximately $2.6 \%$ of nitrogen (Gross et al., 2000). However, the raw protein in shrimp feed does not significantly affect the accumulation of nitrogen in the system (Prangnell et al. 2016), but, in tilapias biofloc systems, nitrogen increases with the levels of protein present in the feed (Azim \& Little, 2008). In the present study, $3.03 \%$ of nitrogen was found in the biofloc meal (Table 2). This is similar to that found in sludge from O. niloticus and rainbow trout, Oncorhynchus mykiss, 
production systems where the reported nitrogen was $2.74 \%$ (Ingle de la Mora et al., 2003).

Calcium was the nutrient with the highest presence in the residual sediment collected over 6 months of red tilapia production in BFT (6.96\%). This result was lower than reported for O. niloticus diets with inclusion of 25 or $50 \%$ floc meal (Mabroke et al., 2019). The variations in the results may be related to the fact that different levels of calcium carbonates are supplied in the biofloc system to maintain alkalinity levels, which is reflected in the levels of this nutrient in the sediments (Furtado et al., 2014). Nutrients are recycled and can accumulate owing to little or no water exchange in the biofloc system (Martins et al., 2017).

The zootechnical performance of tilapias fed with diets containing fish sediment meal (Table 3) were similar to those reported by Prabu et al. (2017), mainly in the FCR when feeds for Nile tilapia were enriched with $20 \%$ biofloc and lysine. The best FCR results were observed using $20 \%$ biofloc and $1.2 \%$ lysine (1.06), and the lowest using $20 \%$ biofloc and $1.8 \%$ lysine. In addition, FCR values were superior than related by Mabroke et al. (2019) for Nile tilapias fed with diets including of 25 or $50 \%$ floc meal for 56 days. Nevertheless, it was found that the amounts of sediment are not constant enough for large-scale production. In sea cucumbers, $A$. japoinicus fed with increasing levels of biofloc meals, a remarkable downward trends on zootechnical parameters was observed as dietary biofloc level increased from $30 \%$ to $60 \%$ (Chen et al., 2018). Therefore, future studies addressing different proportions of biofloc meals for red tilapias should be designed.

Nutritional composition analyses (Table 4) indicate that tilapias fed with fish sediments had moisture and protein levels of $72.28 \%$ and $16.56 \%$, respectively. Results are in agreement with prior values obtained for red hybrid tilapia fillets (Garduño-Lugo et al., 2007). Additionally, results are similar to those reported by Carneiro et al. (2017) in Nile tilapias fed diets containing 30\% digestible protein based on soybean and corn meal, resulting in $16.2 \%$ of body protein. However, crude lipid in our study were higher (7.8\%) than those found by Carneiro et al. (2017) in Nile tilapias (4.1\%). This fact can be explained by the use of tallow, and not soybean oil, in the formulation of the present study.

The microbial flora of fish depends specifically on the microorganisms present in the water where they are grown, the feed used, or the slaughter process used (Boari et al., 2008). Staphylococcus aureus and Escherichia coli are not natural microbiota of fish and can be associated with fish fillets as a consequence of poor water quality or contamination during the food production chain (Roberts et al., 2005; Gatti et al., 2014). The analysis of microbiological requirements (Table 5) determined that tilapias fed with fish sediments comply with the local regulations for S. aureus and E. coli counts on fish fillets (Suarez, 2017). Salmonella spp. and Vibrio spp. could cause foodborne diseases, and are present in regions with high water temperature or polluted waters (Huss, 1994). Satisfactory, in the present study none of such bacteria was found in the red tilapia fillets. The results of this study confirm that the final product can be consumed and that the drying and grinding process performed with the
Table 3. Productive performance parameters of red tilapia fed with a diet containing biofloc meal.

\begin{tabular}{lc}
\hline \multicolumn{1}{c}{ Parameter } & Result \\
\hline WG g & $166 \pm 6$ \\
DWG g/d & $1.84 \pm 0.06$ \\
Biomass kg & $186.2 \pm 9.8$ \\
FCR & $1.23 \pm 0.03$ \\
S \% & 98 \\
\hline
\end{tabular}

WG: Weight gain, DWG: Daily weight gain, FCR: Feed conversion rate, S: Survival.

Table 4. Bromatological analysis of tilapias fed with a diet containing biofloc meal.

\begin{tabular}{lc}
\hline \multicolumn{1}{c}{ Parameters in $\mathrm{g} / 100 \mathrm{~g}(\%)$} & Result \\
\hline Moisture & 72.28 \\
Ash & 2.78 \\
Crude lipid & 7.80 \\
Crude protein & 16.56 \\
Total carbohydrates & 0.58 \\
Calories & 138.74 \\
Raw fiber & $\mathrm{ND}$ \\
\hline
\end{tabular}

ND: Non-detected.

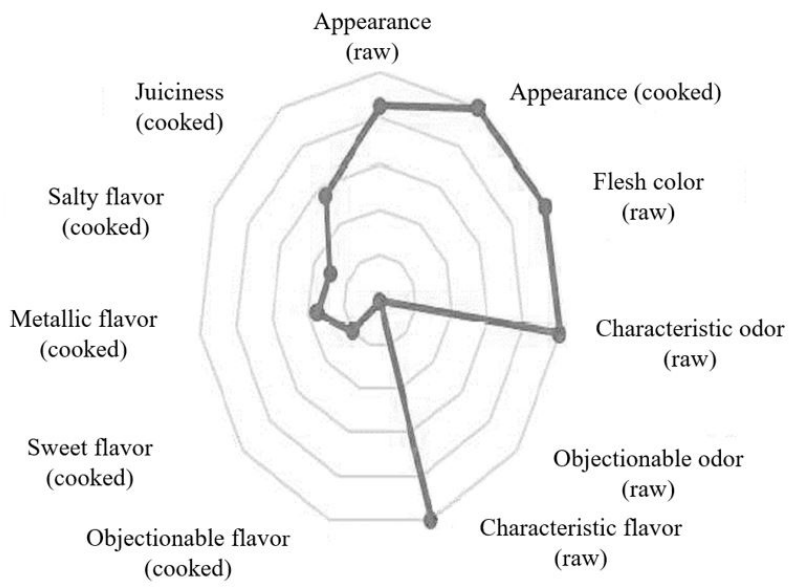

Figure 1. Intensities of sensory descriptors for tilapias fed with a diet containing biofloc meal.

fish sediments reduced the risk of contamination with human pathogenic microorganisms.

The sensory technical data sheet (Table 6, Figure 1) showed that the characteristic flavor as well as the appearance was very strong when the product was cooked. These results can be affected by storage and preparation. However, it was evident that the results are similar to those reported for red hybrid tilapias fed with alternatives ingredients to fish oil, where it was concluded that this factor did not affect the sensory attributes of the product (Ng \& Bahurmiz, 2009). 
Table 5. Microbiological analysis of red tilapias fed with a diet containing biofloc meal.

\begin{tabular}{lccc}
\hline \multicolumn{1}{c}{ Analysis } & Criterion or specifications & Results & Compliance \\
\hline E. coli & $10-400 \mathrm{UFC} / \mathrm{g}$ & 40 & Complies \\
Coagulase-positive Staphylococcus & $100-1000 \mathrm{UFC} / \mathrm{g}$ & $<100$ & Complies \\
aureus & Absence/25 g & Absence & Complies \\
Salmonella spp. & Absence/25g & Absence & Complies \\
Vibrio cholerae & &
\end{tabular}

Table 6. Intensity rating of sensory descriptors for tilapias fed with a diet containing biofloc meal.

\begin{tabular}{|c|c|c|c|c|}
\hline \multirow{2}{*}{ Descriptors } & \multicolumn{2}{|c|}{ Product } & \multirow{2}{*}{$\begin{array}{l}\text { Whole gutted and scaleless } \\
\text { tilapia }\end{array}$} & \multirow{2}{*}{ Intensity } \\
\hline & Cooked & Raw & & \\
\hline Appearance & & $\mathrm{x}$ & 8.5 & Strong \\
\hline Flesh color & & $\mathrm{x}$ & 10 & Very strong \\
\hline Characteristic odor & & $\mathrm{x}$ & 10 & Very strong \\
\hline Characteristic flavor & $\mathrm{x}$ & & 10 & Very strong \\
\hline Objectionable flavor & $\mathrm{x}$ & & 0.0 & Absence \\
\hline Sweet flavor & $\mathrm{x}$ & & 2.0 & Very mild \\
\hline Metallic flavor & $\mathrm{x}$ & & 3.5 & Mild \\
\hline
\end{tabular}

Table 7. Water quality parameters during the feeding trial.

\begin{tabular}{lcc}
\hline \multicolumn{1}{c}{ Parameters } & $\begin{array}{c}\text { Reference values } \\
\text { (Boyd \& Massaut, } \\
1999)\end{array}$ & Present study \\
\hline Dissolved oxygen $(\mathrm{ppm})$ & $>3$ & $4.1 \pm 0.1$ \\
Oxygen saturation (\%) & $50-70$ & $60.1 \pm 8.3$ \\
Temperature $\left({ }^{\circ} \mathrm{C}\right)$ & $24-30$ & $27.4 \pm 1.2$ \\
$\mathrm{pH}$ & $6.5-8$ & $7.5 \pm 0.3$ \\
TDS (ppm) & $<1000$ & $990 \pm 123$ \\
EC $\left(\mu \mathrm{Scm}{ }^{-1}\right)$ & $<1000$ & $832 \pm 67$ \\
Ammonia $(\mathrm{ppm})$ & $<1$ & $0.2 \pm 0$ \\
Nitrite $(\mathrm{ppm})$ & $<1$ & $0.1 \pm 0$ \\
Nitrate $(\mathrm{ppm})$ & $10-200$ & $10 \pm 0.4$ \\
Orthophosphates $\left(\mathrm{mgL}^{-1}\right)$ & $1-10$ & $0.254 \pm 0.1$ \\
Alkalinity $(\mathrm{ppm})$ & $>120$ & $122 \pm 16$ \\
DS (ppm) & $25-50$ & $21 \pm 0.4$ \\
\end{tabular}

TDS: Total dissolved solids, EC: electrical conductivity, DS: decantable solids.

The water quality parameters (Table 7) were within the ranges indicated for the species (Boyd \& Massaut, 1999). The nitrogenous compounds were not affected by the diet, which could possibly be owing to the continuous water exchanges, which did not allow the accumulation of these nutrients in the water.

\section{Conclusion}

The present study relates that red tilapia sediments from BFT tanks have appropriate levels of protein, and that the zootechnical performance of red tilapias fed with diets containing the biofloc meal was adequate for the species and the production stage. In addition, the raw feed did not interfere with the microbiological, bromatological and sensory quality of the final product. However, the amounts of sediment are not constant and therefore are not sufficient for commercial-scale feed production, but they can be used as a supplement in small fish facilities. Finally, further studies are needed including comparisons between common commercial diets for tilapia and different levels of inclusion of the biofloc meal.

\section{Acknowledgements}

We/The authors thank Crimson Interactive Pvt. Ltd. (Enago) - https://www.enago.com/es/ for their assistance in manuscript translation and editing.

\section{References}

American Public Health Association - APHA. (2005). Standard Methods for the Examination of Water and Wastewater (21th ed.). Washington: American Public Health Association/American Water Works Association and Water Pollution Control Association.

Amerine, M. A., Pangborn, R. M., \& Roessler, E. B. (1965). Principles of sensory evaluation of food. New York: Academic Press. 
Anand, P. S., Kohli, M. P. S., Kumar, S., Sundaray, J. K., Roy, S. D., Venkateshwarlu, G., Sinha, A., \& Pailan, G. H. (2014). Effect of dietary supplementation of biofloc on growth performance and digestive enzyme activities in Penaeus monodon. Aquaculture (Amsterdam, Netherlands), 418, 108-115. http://dx.doi.org/10.1016/j. aquaculture.2013.09.051.

Association of Official Analytical Chemists - AOAC. (2012). Official Methods of Analysis (19th ed.). Washington: AOAC.

Avnimelech, Y. (2009). Biofloc technology. A practical guide book. Baton Rouge: The World Aquaculture Society.

Azim, M. E., \& Little, D. C. (2008). The biofloc technology (BFT) in indoor tanks: water quality, biofloc composition, and growth and welfare of Nile tilapia (Oreochromis niloticus). Aquaculture (Amsterdam, Netherlands), 283(1-4), 29-35. http://dx.doi.org/10.1016/j. aquaculture.2008.06.036.

Bauer, W., Prentice-Hernandez, C., Tesser, M. B., Wasielesky, W. Jr, \& Poersch, L. H. (2012). Substitution of fishmeal with microbial floc meal and soy protein concentrate in diets for the pacific white shrimp Litopenaeus vannamei. Aquaculture (Amsterdam, Netherlands), 342, 112-116. http://dx.doi.org/10.1016/j.aquaculture.2012.02.023.

Boari, C. A., Pereira, G. I., Valeriano, C., Silva, B. C., Morais, V. M. D., Figueiredo, H. C. P., \& Piccoli, R. H. (2008). Bacterial ecology of tilapia fresh fillets and some factors that can influence their microbial quality. Food Science and Technology (Campinas), 28(4), 863-867. http://dx.doi.org/10.1590/S0101-20612008000400015.

Boyd, C. E., \& Massaut, L. (1999). Risks associated with the use of chemicals in pond aquaculture. Aquacultural Engineering, 20(2), 113-132. http://dx.doi.org/10.1016/S0144-8609(99)00010-2.

Brú-Cordero, S. B., Pertúz-Buelvas, V., Ayazo-Genes, J., Atencio-García, V. J., \& Pardo-Carrasco, S. (2017). (2017). Cachama (Piaractus brachypomus) and Nile Tilapia (Oreochromis niloticus) -Biculture In Biofloc Fed Diets Of Vegetable Origin. Revista de la Facultad de Medicina Veterinaria y Zootecnia, 64(1), 44-60. http://dx.doi. org/10.15446/rfmvz.v64n1.65824.

Carneiro, W. F., Pandini, F., Silva, L. C. R. D., Santos, L. D. D., Rossato, K. A., \& Meurer, F. (2017). Digestible protein requirement for Nile tilapia fed with rations based on soybean meal and corn. Acta Scientiarum. Animal Sciences, 39(4), 343-349. http://dx.doi. org/10.4025/actascianimsci.v39i4.36122.

Chen, J., Liu, P., Li, Y., Li, M., \& Xia, B. (2018). Effects of dietary biofloc on growth, digestibility, protein turnover and energy budget of sea cucumber Apostichopus japonicus (Selenka). Animal Feed Science and Technology, 241, 151-162. http://dx.doi.org/10.1016/j. anifeedsci.2018.05.002.

Crab, R., Defoirdt, T., Bossier, P., \& Verstraete, W. (2012). Biofloc technology in aquaculture: beneficial effects and future challenges. Aquaculture (Amsterdam, Netherlands), 356, 351-356. http://dx.doi. org/10.1016/j.aquaculture.2012.04.046.

Delgado, D. L. C., Rubio, N. C., Rodríguez, F. A. M., Torres, C. A. B., \& Aguinaga, J. Y. (2018). Diagnóstico clínico de monogeneos en alevinos de piscicultura intensiva en Arauca. Intropica, 13(1), 57-63. Retrieved from: http://revistas.unimagdalena.edu.co/index. php/intropica/article/view/2356/1733

Ebeling, J. M., Timmons, M. B., \& Bisogni, J. (2006). Engineering analysis of the stoichiometry of photoautotrophic, autotrophic, and heterotrophic removal of ammonia-nitrogen in aquaculture systems. Aquaculture (Amsterdam, Netherlands), 257(1-4), 346-358. http:// dx.doi.org/10.1016/j.aquaculture.2006.03.019.

Furtado, P. S., Gaona, C. A., Poersch, L. H., \& Wasielesky, W. Jr. (2014). Application of different doses of calcium hydroxide in the farming shrimp Litopenaeus vannamei with the biofloc technology
(BFT). Aquaculture International, 22(3), 1009-1023. http://dx.doi. org/10.1007/s10499-013-9723-9.

Garduño-Lugo, M., Herrera-Solís, J. R., Angulo-Guerrero, J. O., Muñoz-Córdova, G., \& De la Cruz-Medina, J. (2007). Nutrient composition and sensory evaluation of fillets from wild-type Nile tilapia (Oreochromis niloticus, Linnaeus) and a red hybrid (Florida red tilapia $\times$ red O. niloticus). Aquaculture Research, 38(10), 10741081. http://dx.doi.org/10.1111/j.1365-2109.2007.01773.x.

Gatti, P. Jr., Assunção, A. W. A., Baldin, J. C., \& Amaral, L. A. (2014). Microbiological quality of whole and filleted shelf-tilapia. Aquaculture (Amsterdam, Netherlands), 433, 196-200. http://dx.doi.org/10.1016/j. aquaculture.2014.06.015.

Gross, A., Boyd, C. E., \& Wood, C. W. (2000). Nitrogen transformations and balance in channel catfish ponds. Aquacultural Engineering, 24(1), 1-14. http://dx.doi.org/10.1016/S0144-8609(00)00062-5.

Hargreaves, J. Á. (2013). Biofloc production systems for aquaculture (SRAC Publication, No 4503). Stoneville: Southern Regional Aquaculture Center Publication.

Huss, H. H. (1994). Assurance of seafood quality. Rome: FAO. Retrieved from: http://www.fao.org/docrep/003/t1768e/t1768e00.htm

Ingle de la Mora, G., Villareal-Delgado, E. L., Arredondo-Figueroa, J. L., Ponce-Palafox, J. T., \& Barriga-Sosa, I. D. L. A. (2003). Evaluación de algunos parámetros de calidad del agua en un sistema cerrado de recirculación para la acuicultura, sometido a diferentes cargas de biomasa de peces. Hidrobiológica, 13(4), 247-253.

Ju, Z. Y., Forster, I., Conquest, L., \& Dominy, W. (2008). Enhanced growth effects on shrimp (Litopenaeus vannamei) from inclusion of whole shrimp floc or floc fractions to a formulated diet. Aquaculture Nutrition, 14(6), 533-543. http://dx.doi.org/10.1111/j.1365-2095.2007.00559.x.

Kuhn, D. D., Boardman, G. D., Lawrence, A. L., Marsh, L., \& Flick, G. J. Jr. (2009). Microbial floc meal as a replacement ingredient for fish meal and soybean protein in shrimp feed. Aquaculture (Amsterdam, Netherlands), 296(1-2), 51-57. http://dx.doi.org/10.1016/j. aquaculture.2009.07.025.

Kuhn, D. D., Lawrence, A. L., Boardman, G. D., Patnaik, S., Marsh, L., \& Flick, G. J. Jr. (2010). Evaluation of two types of bioflocs derived from biological treatment of fish effluent as feed ingredients for Pacific white shrimp, Litopenaeus vannamei. Aquaculture (Amsterdam, Netherlands), 303(1-4), 28-33. http://dx.doi.org/10.1016/j. aquaculture.2010.03.001.

Luo, G., Chen, X., Tan, J., Abakari, G., \& Tan, H. (2020). Effects of carbohydrate addition strategy and biofloc levels on the establishment of nitrification in biofloc technology aquaculture systems. Aquaculture (Amsterdam, Netherlands), 514, 734441. http://dx.doi.org/10.1016/j. aquaculture.2019.734441.

Luo, G., Xu, J., \& Meng, H. (2019). Nitrate accumulation in biofloc aquaculture systems. Aquaculture (Amsterdam, Netherlands), 520, 734675. https://doi.org/10.1016/j.aquaculture.2019.734675.

Luo, G., Zhang, N., Cai, S., Tan, H., \& Liu, Z. (2017). Nitrogen dynamics, bacterial community composition and biofloc quality in biofloc-based systems cultured Oreochromis niloticus with poly$\beta$-hydroxybutyric and polycaprolactone as external carbohydrates. Aquaculture (Amsterdam, Netherlands), 479, 732-741. http://dx.doi. org/10.1016/j.aquaculture.2017.07.017.

Mabroke, R. S., El-Husseiny, O. M., Zidan, A. E. N. F., Tahoun, A. A., \& Suloma, A. (2019). Floc meal as potential substitute for soybean meal in tilapia diets under biofloc system conditions. Journal of Oceanology and Limnology, 37(1), 313-320. http://dx.doi. org/10.1007/s00343-019-7222-1. 
Martins, G. B., Tarouco, F., Rosa, C. E., \& Robaldo, R. B. (2017). The utilization of sodium bicarbonate, calcium carbonate or hydroxide in biofloc system: water quality, growth performance and oxidative stress of Nile tilapia (Oreochromis niloticus). Aquaculture (Amsterdam, Netherlands), 468, 10-17. http://dx.doi.org/10.1016/j. aquaculture.2016.09.046.

Mbahinzireki, G. B., Dabrowski, K., Lee, K. J., El-Saidy, D., \& Wisner, E. R. (2001). Growth, feed utilization and body composition of tilapia (Oreochromis sp.) fed cottonseed meal-based diets in a recirculating system. Aquaculture Nutrition, 7(3), 189-200. http:// dx.doi.org/10.1046/j.1365-2095.2001.00172.x.

Najdegerami, E. H., Bakhshi, F., \& Lakani, F. B. (2016). Effects of Biofloc on growth performance, digestive enzyme activities and liver histology of common carp (Cyprinus carpio L) fingerlings in zero-water exchange system. Fish Physiology and Biochemistry, 42(2), 457-465. http://dx.doi.org/10.1007/s10695-015-0151-9.

Ng, W. K., \& Bahurmiz, O. M. (2009). The impact of dietary oil source and frozen storage on the physical, chemical and sensorial quality of fillets from market-size red hybrid tilapia, Oreochromis sp. Food Chemistry, 113(4), 1041-1048. http://dx.doi.org/10.1016/j. foodchem.2008.08.060.

Prabu, E., Rajagopalsamy, C. B. T., Ahilan, B., Santhakumar, R., \& Jemila, A. (2017). Influence of Biofloc meal and Lysine supplementation on the growth performances of GIFT tilapia. Journal of Entomology and Zoology Studies, 5(5), 35-39.

Prangnell, D. I., Castro, L. F., Ali, A. S., Browdy, C. L., Zimba, P. V., Laramore, S. E., \& Samocha, T. M. (2016). Some limiting factors in superintensive production of juvenile Pacific white shrimp,
Litopenaeus vannamei, in no-water-exchange, biofloc-dominated systems. Journal of the World Aquaculture Society, 47(3), 396-413. http://dx.doi.org/10.1111/jwas.12275.

Roberts, T. A., Cordier, J. L., Gram, L., Tompkin, R. B., Pitt, J. I., Gorris, L. G. M., \& Swanson, K. M. J. (Eds.), (2005). Micro-organisms in foods 6: microbial ecology of food commodities. London: Springer. http://dx.doi.org/10.1007/0-387-28801-5.

Suarez, L. E. P. (2017). Calidad fisicoquímica y microbiológica de dos especies de pescados dulceacuícolas comercializados en el municipio de Sincelejo-Colombia (Trabajo de conclusión de grado). Universidad de Sucre, Sincelejo, Sucre, Colombia. Retrieved from https://repositorio. unisucre.edu.co/jspui/bitstream/001/562/1/T597.0929\%20S939.pdf

Wei, Y. F., Wang, A. L., \& Liao, S. A. (2020). Effect of different carbon sources on microbial community structure and composition of ex-situ biofloc formation. Aquaculture (Amsterdam, Netherlands), 515, 734492. http://dx.doi.org/10.1016/j.aquaculture.2019.734492.

Xu, W. J., \& Pan, L. Q. (2012). Effects of bioflocs on growth performance, digestive enzyme activity and body composition of juvenile Litopenaeus vannamei in zero-water exchange tanks manipulating $\mathrm{C} / \mathrm{N}$ ratio in feed. Aquaculture (Amsterdam, Netherlands), 356, 147-152. http:// dx.doi.org/10.1016/j.aquaculture.2012.05.022.

Xu, W. J., \& Pan, L. Q. (2014). Evaluation of dietary protein level on selected parameters of immune and antioxidant systems, and growth performance of juvenile Litopenaeus vannamei reared in zero-water exchange biofloc-based culture tanks. Aquaculture (Amsterdam, Netherlands), 426, 181-188. http://dx.doi.org/10.1016/j. aquaculture.2014.02.003. 